\title{
Canadian University and Reference Libraries in Wartime
}

As librarian of the National Research Council of Canada, Miss Gill is in position to observe the effects of the war upon many of the libraries in her country.

Canada went to war in September C 1939 and to the classes graduating in 1943 from Canadian universities the abnormal life of wartime was the normal life of an undergraduate who had known no other. Librarians, however, whose memories and records go back to the prewar days, when life was not necessarily all part of the nation's war effort, have contributed various notes and reports from which the following has been compiled.

\section{Book Supply}

From east to west there is general agreement on certain outstanding disabilities under which libraries are struggling. Chief among these is the increased cost of books, due mainly to the rate of exchange between Canada and the United States and to the special war import tax of Io per cent collected by the Canadian government. The University of Saskatchewan library reckoned early in 1942 that the cost of books had then risen 32 per cent. More recently a technical book listed in the United States at ten dollars was offered by agents in Toronto at fourteen dollars. This is a serious handicap, not only to libraries endeavoring to meet the growing needs of their borrowers, but also to the individual, whether student, technician, or researcher, who cannot afford the books he would normally hope to buy for himself.

Closely allied to the question of initial cost is that of poor quality of paper and binding, necessitating early replacement, which in turn is made difficult by the limited editions printed. The small number and poor quality of many books printed in Great Britain, coupled with the delay and uncertainty of delivery, have reduced one of the principal sources of supply to a small fraction of its prewar usefulness.

A major calamity in the reference library is the periodical situation. Canada's files of foreign journals were successively cut off with each advance of Axis aggression. The last issues from Germany arrived in September 1939. Those from Scandinavia, Holland, Belgium, Italy, and France followed in their turn in 1940, and so on. Some of the earlier numbers that failed to reach Canada were received, in limited quantities, in the United States and have been available for photostat or microfilm copying, but there are still many that seemingly have not reached either country. Although missing issues of British journals are surprisingly few, there are enough to cause troublesome breaks in files that cannot at present be remedied, and in 1942 missing numbers of United States publications were added to the 
problem. The answer to a routine report that a certain issue has not arrived is usually, "So sorry! But we have no more copies." Sometimes the cold comfort of a month's extension of the subscription is offered, but this does nothing for the broken file. Incidentally, the size and form of some. British publications present a binding problem that is not easily solved.

\section{Staff Difficulties}

The next major handicap under which Canadian libraries are struggling is also one shared with other countries. It is the lack of adequate staff. Trained assistants have left to enter the armed forces or to do work more obviously connected with the war effort, and the library schools are graduating fewer students than ever before. The librarian of McGill University summarizes the situation by saying: "It is impossible to replace trained assistants owing to (a) higher salaries paid in special libraries, (b) lack of unplaced library school graduates, (c) diversion of possible library school students to war activities." Opportunities in other lines of work at higher salaries have cut down the supply of potential pages, messengers, and janitor staff, and it has been said that it is easier to get a qualified engineer than a good stenographer. This situation has indirectly had a beneficial effect on salaries in some institutions where it was found impossible to get new staff members without offering higher commencing salaries than had obtained formerly. Frequently older members have had to have increases to bring them level with the newcomers.

The war departments of the federal government have drawn a large number of librarians to Ottawa where they are serving in many guises. It is unfortu- nately true that many good librarians have found that they can get better salaries, doing work for which their library training makes them particularly adapted, if they are listed under some caption other than "librarian." Librarianship seems to rank with virtue when the monetary rewards are being handed out! However, the fact remains that whatever their classification in the civil service records, many librarians have found their way to Ottawa, leaving gaps in the staffs across the country that cannot be easily filled.

\section{Industrial Aid}

Their location relative to defense training centers or industrial areas, particularly in those places where other libraries are inadequate or entirely lacking, has been largely responsible for the part played by some libraries in the recreational and educational life of men in those centers. McGill University lists the following under the heading LOANS AND CIRCULATION :

1. Greatly increased use of the library by research workers in war plants, industries, and scientific laboratories.

2. Increase in reference work done by the staff for the above groups.

3. Judicious extension of library rules and regulations for the use of stack for properly recommended members of the above groups.

4. Increased undergraduate use of the library and more numerous calls for assistance on the part of the library staff.

5. Use of the library, for the first time, by members of the Navy, Army, and Air Forces of the United Nations for both informative and recreational reading, and extension of library rules to include these groups,

6. Adult education groups and educational specialists use the library facili- 
ties more than ever, especially with regard to postwar planning.

7. Establishment of a special reference shelf on world conditions and current events.

8. Active cooperation with the International Labour Office and National Research Council by allowing access to all our resources and providing help when possible.

9. Collection of books and periodicals for the Central Book and Magazine Depot for distribution to the armed services.

Io. Loans to internment and refugee camps for educational use.

I I. Marked increase in providing libraries and research agencies with photostats and film copies.

McGill, like the libraries of British Columbia, has taken precautions to protect its more valuable treasures against possible air raids by removing them to safe storage.

\section{Service to Military Units}

Although thirty miles from their camp, Mount Allison has given much appreciated service, particularly recreational reading, to the R.A.F. men stationed in Moncton. The Provincial Library in Victoria reports that a large number of Navy, Army, and Air Force personnel have made use of the library for both personal and official purposes. The provincial librarian writes:

I might mention in this connection cooperation with Royal Roads Naval College and H.M.C. Dockyard. Special note should be made of operations which we have happily been able to carry out for the benefit of Canadian Naval Intelligence, Army Map Service of the United States Corps of Engineers, and United States Army Intelligence, in the matter of collecting maps, aerial photographs, and other important material from various sources throughout the province....
Several institutions, including Ontario Agricultural College, Macdonald College, University of Manitoba, and McMaster University, have given the use of one or more buildings to the armed forces. This has necessitated, on the one hand, a rearrangement of the classes or other activities normally held there and, on the other hand, a greater contact with the men and women thus introduced to the campus, who are usually given extensive library privileges.

\section{Diversified Contributions}

Mount Saint Vincent College Library offers an interesting example of the contribution such an institution can make to the cultural life of its community. As part of a young, rather small, liberal arts college for women, situated four miles outside Halifax, the library has had little direct contact with the services but has endeavored to help the students in their understanding of the present and in their intelligent choice of a career for the future. Through a small branch library at the entrance to the campus, the staff serves the people of the district, especially the children of the village, and gradually the reading interests of these young Canadians have been extended from the familiar things of their everyday life to include stories of other children in other lands, and the elders have been led on from Pearl Buck's Patriot and Dragon Seed to The Soong Sisters and the speeches of the Chiangs and from The Family and The Children to many other books on Russia. The librarian, Sister Francis de Sales, writes, "Is not this enlarging of sympathy and intelligent interest furthering our war aims and preparing for the brave new world we all prayerfully envisage?"

The librarian of L'Institut Agricole 
d'Oka reports that he is working singlehanded to carry on all the usual routines of his library and, in addition, to do detailed indexing under English, French, and Latin names for the benefit of the French-Canadian "agronomes" of the Province of Quebec. With a practically nonexistent budget the library is largely dependent on friendly institutions (agricultural experiment stations, libraries, etc.) which make their publications available free of charge.

In some universities provision has been made for new courses, especially wartime technical courses, and the libraries have had to do more extensive buying in these fields than was formerly necessary. The University of Saskatchewan mentions also an increased interest in current affairs, campaigns, and postwar problems which have led to an increased output of and demand for books on current topics in economics, politics, and military matters. This in turn adds to the problems of book selection in institutions working on very limited budgets.

\section{Effects on Use}

Circulation statistics have reflected various influences in different localities. Mount Allison reports a fluctuation in "outside" reading but feels that the lack of leisure time which seemingly accounted for a temporary drop was also responsible for a keener interest in the reading that was done and for an increase of 100 per cent in the circulation of periodicals and pamphlets. British Columbia attributes a recent drop in circulation to the war, "either to the military drill, etc., required of students, which took time they would otherwise have spent reading, or to preoccupation with the war news. There was at times a strikingly close relation between the work being done by the students and the progress of the war."

Acadia likewise relates the war news and the use of the library:

We were forced to conclude that the students' interest in books was adversely affected by the war. During the first year we attributed this to the prevailing spirit of unrest and apprehension; during the next two years to the time consumed in war activities-daily drill by the men and Red Cross work by the women; during 1942-43 to an actual mental laziness induced by abnormal conditions and continuous bad news.... Since college opened this autumn (1943) a totally different spirit seems to prevail. There is a large attendance of new students. ... The reading rooms are usually well filled with studious and attentive young men and women. Perhaps a hope of victory underlies this attitude. The word "postwar" is heard daily in the classrooms and on the campus. To sum up, at the beginning of the war and while the final victory seemed doubtful, the purely intellectual interests could scarcely be emphasized at Acadia. Scholarship in its deepest human values was obliged to give way even in the university library to frantic efforts of untrained minds to comprehend the details of the struggle and to be technically prepared to take part in it. Succeeding this phase was one of intellectual apathy. Now the time-honored values of what Charles Lamb called the "academic institution" seem to be once more emerging. Hope and aspiration assume their age-old character, without which a university library would soon become meaningless.

\section{Work of Medical Libraries}

Meeting the same problems of book and periodical supply, shortage and cost of equipment, lack of staff, etc., that are faced by the general university library, the medical branch has been struggling to serve the often highly specialized needs of a greatly augmented clientele engaged in research and investigational work cov- 
ering a wide subject field. As a wartime measure medical courses were considerably speeded up and the activities of the medical libraries were correspondingly modified. Dalhousie reports, "Speeding up of the courses caused the students to work harder and more continuously. Crowding in boarding houses meant that more studying was done in the library, and the library had to be kept open longer hours in the evenings, noon-hours, week ends, and holidays." The medical men in the services are among the libraries' regular patrons and every effort has been made to provide any immediate information required as well as to offer the advantages of free access to books, indexes, and journals-a boon seldom enjoyed in ordinary practice. The Medical Library of the University of Western Ontario, for example, has made special efforts to assist the medical men in the military district of which London is the headquarters, particularly in the field of war medicine, with the result that, although circulation figures for the general library showed a considerable decrease from prewar years, loans from the medical library had increased appreciably.

\section{Reference Libraries}

The conditions that affect the university library are, with the exception of purely institutional factors, also the concern of the reference department of the public or special library. A recent report from the Vancouver Public Library states that questions asked in the science and industry division there have been "of a considerably higher calibre than in the prewar days" and indicate that people are taking a much greater interest in important issues of the day.

Without a doubt the outstanding interest of people today, apart from the war itself, is the question of postwar reconstruction. ... The winning of this war is inextricably bound up with the kind of a world we are going to have after it. ... So we are deluged on every side by study groups, forums, boards of trade, political parties, clubs, and individuals, for material on reconstruction and conversion of war industry into peacetime industry. This question so predominates over all others that it is encouraging to say the least and gives some hope to an adult education program on a large scale which will involve libraries in a manner in which they have never been involved before. ...

As one means of answering present and future problems presented by the upheaval in manufacturing and industrial life and recognizing the public library's opportunity to serve business and the worker, the Toronto Public Library in I94I expanded its reference division to include a separate business and technology section where scientific and technical men, students, and workers might find the information needed to help them in either their immediate or postwar occupations.

\section{Summary}

And so the story goes. In reading reports from libraries in all parts of Canada it is soon apparent that certain general effects of the war are felt everywhere. The slowness and uncertainty of deliveries, the gaps in periodical files (especially of foreign journals), the inferior quality of paper and workmanship, the shortage of some supplies and complete lack of others, are wartime hardships common to libraries in many countries. But Canadian libraries are carrying a special burden in the increased cost of books. Quite apart from local conditions that may influence its activities (such as the presence of a training center on or near the campus) 
every library in Canada is directly affected by the extra cost added by federal taxes and the exchange rate to the list price of books and periodicals published in the United States, the obvious and chief source of supply.

Added to this is the staff problem. With the country's comparatively small reservoir of trained librarians the drain to war work in one form or another is a much more serious loss than might seem on first thought to be the case. Candidates for admission to library schools are fewer than ever before and usually have positions waiting for them after graduation. Many members of the profession are deeply concerned lest the lack of qualified workers lead to the acceptance of unqualified people, resulting in a lower standard of service and further delay in the recognition of the library profession through certification requirements and adequate salary adjustments.

- On the bright side of the picture is the fact that a large section of the public has become for the first time "library conscious." It is increasingly apparent that the keener minds concerned with the nation's business are well aware of the library's potentialities, and there is reason to hope that the reconstruction period will bring opportunities for development never before thought possible. Representations have been made to federal and provincial reconstruction committees emphasizing the importance of adequate library service in the educational and intellectual life of a democratic community and urging the establishment of a nationwide plan that would remove some of the handicaps suffered by those living in districts too remote and sparsely settled to support library service without outside help and still less able to buy books for their homes. The correlation of national, provincial, regional, and local library units, existing or to be established, and the appointment of a commission to advise the government on library policy, are among the recommendations made in briefs submitted by various library agencies, pointing out that the need for libraries is correspondingly greater in a country where the price of books is higher than in almost any other civilized country, making them too costly for any but very limited private buying.

Canada's lack of a national library was first publicized over thirty years ago by Dr. Lawrence J. Burpee, now Canadian Secretary of the International Joint Commission, and was again brought into the headlines in the late summer of 1943 by a report from the general librarian of the Parliamentary Library to the Library Committee of the House of Commons and Senate, in which the present dire state of the Parliamentary Library was dealt with. The establishment of a national library would greatly help the older institution, leaving it free to fulfil its constitutional function, and would be a very important step in strengthening the intellectual and cultural life of the nation. The report was adopted by the committee, which went on record as approving the recommendations. Any resulting action will be of incalculable importance to all libraries in Canada, giving new life and impetus to library and educational activities throughout the country. In spite of many grim realities of the war years, Canadian librarians are looking forward to the postwar period with increasing hope that some at least of its almost unlimited possibilities may soon become realities. 